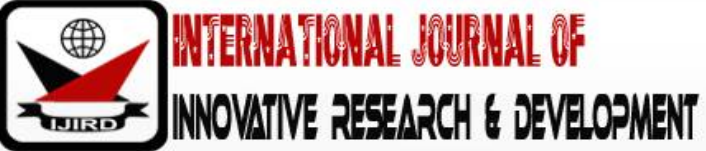

ISSN 2278 - 0211 (Online)

\section{Moderating Influence of Institutional Framework on the Relationship between Participatory Forest Management and Mau Forest Conservation Programme in Kenya}

\begin{tabular}{c}
\hline Julius Kibet Cheruiyot \\
Ph.D. Candidate, School of Open and Distance Learning, Kenya \\
University of Nairobi \\
Dr. Lillian Otieno Omutoko \\
Senior Lecturer, Department of Open Learning, University of Nairobi, Kenya \\
Charles Rambo \\
Professor, School of Open and Distance Learning, University of Nairobi, Kenya \\
\hline
\end{tabular}

\begin{abstract}
:
Forest performs a wide range of critical environmental and climatic functions and serves as homes to the majority of the world's plant and animal species. However, forests and forest resources are currently declining substantially, thus threatening the current and future local communities' ability to meet their basic needs from the forest. Many countries, particularly in Asia and Africa have since undertaken review of policies and legislation on forestry to incorporate aspects of Participatory Forest Management to conserve and manage resources in a sustainable way. The objective of the study was to determine the moderating influence of institutional framework on the relationship between institutional framework and Mau forest conservation programme. This study was grounded on Forest Transition Theory and guided by descriptive survey design and correlational research design. A sample size of 364 respondents was drawn from a target population of 4100 people using Yamane (1967) Formula. Quantitative data was collected through a selfadministered structured questionnaire while qualitative data was collected through an interview guide. From the findings, with Model1:p-value=0.007 and Model 2:Z=-0.189,p-value=0.005, the null hypothesis was rejected and concluded that there is a significant relationship between the moderating influence of institutional framework on the relationship between Participatory Forest Management and Mau Forest conservation programme. This study recommends that creation of local institutions are essential for conservation of forests but these institutions need resources and capacity development for sustainability of forest conservation programs.
\end{abstract}

Keywords: Participatory forest management, institutional framework, conservation, forests, moderating influence

\section{Introduction}

Forests are considered the second most important natural resource after water throughout the world. Worldwide, forest industries also provide employment for 60 million people while some 1 billion people depend on drugs derived from forest plants for their medicinal needs (World Bank, 2006). They serve as a source of food, oxygen, shelter, recreation, and spiritual sustenance, and they are the source for over five thousand $(5,000)$ commercially-traded products, ranging from pharmaceuticals to timber and clothing (CBD, 2009). Forest performs a wide range of critical environmental and climatic functions and it serves as homes to the majority of the world's plant and animal species. The significance of forest can be classified under environmental, social and economic (Abass, 2007), and based on this humans have historically attached religious, philosophical and aesthetic significance to forest. Forest resources play a key role in protecting the environment and are of tremendous importance to the sustainable development of every society.

The world's total forest area amounts to just over 4 billion hectares, equivalent to $31 \%$ of the total land area, and on average of 0.6 ha per capita (FAO, 2010). In Sub- Saharan Africa and parts of Asia such as Nepal and Bangladesh, rural populations depend, directly or indirectly, on forests for their daily subsistence and income needs (Kaimowitz, 2003; Phiri, Chirwa, Watt and Syampungani, 2012. Participatory Forest Management (PFM) is the local involvement of communities in the management of forests done through a process of inclusion, equity, and democratization of governance of the forest resources (Agrawal and Gupta, 2005). The emphasis on the participation of local stakeholders in natural-resource management has led to an examination of how such an approach has been implemented and its successes and limitations which calls for institutionalization of forest conservation programs.

Based on their study in Asian forest management, Lee and Park (2001) believe that the participation of local people in forest resource management can maintain the integrity of local ecology, that forest co-management can facilitate 
forest protection and development, help to reduce poverty, and to meet their survival needs. In Bangladesh, the program was launched in the 1980s with the objective of involving local communities in managing forest resources. Protection of national forest degradation and rural poverty alleviation were the main motivation behind leasehold forestry in Nepal and joint forest management in India (Pokharel, 2008). In some other countries, such as Honduras, PFM has been associated with government decentralization programme.

In Ethiopia, PFM was recommended by NGOs to solve the problem of forest degradation (Mustalahti, 2006). In recent years, substantial rights and powers over forest resources have been transferred to local democratically elected bodies in Tanzania through participatory forest management (PFM) initiatives. PFMs main objectives include: improvement of forest quality, livelihoods, and local governance of natural resource management institutions (Wily, 2001, URT, 2003).

A study carried out by UNEP (2002) on deforestation in African countries revealed that weak ineffective policies, laws and regulations are seen as the main cause of deforestation. However, it is not only lack of proper government policies and laws that fail the environmental conservation, but the major challenge is in lack of proper functioning institutions that fail to stop over-exploitation of forests. This is also a view taken by Neumann (2005) who argues that states promote environmental degradation through its failure to implement its laws and policies on environmental conservation. This failure, in his view, originates from the historical events and decisions of the state. He notes that, the political economy of the state that emphasizes on more land accumulation and a development that favours forest destruction is the undoing of environmental conservation.

The total forest area is less than 3 per cent of the total land area of Kenya. The decrease in forest cover is primarily due to encroachment, expansion of human settlements into previously forested areas, illegal logging, forest fires; agriculture and government excisions (NEMA, 2009). In total, the forest excision and widespread human encroachments led to a total loss of about 25\% of the more than107, 000 ha in the Mau Forest between 1989 and 2009 (GOK, 2009). Unfortunately the Forest Act has remained largely unimplemented as the institutional structures for the Kenya Forest Service has not been completed and devolution of forest management powers is not yet to take place (Matiku, Ogol and Mireri, 2011). This study was conducted to determine the moderating influence of institutional framework on the relationship between participatory forest management and Mau Forest conservation programme

\subsection{Purpose of the study}

The study sought to determine the moderating influence of institutional framework on the relationship between institutional framework and Mau Forest conservation programme in Kenya

\subsection{Objective of the Study}

To establish how institutional framework moderate the relationship between Participatory Forest Management and Mau Forest conservation programme

\subsection{Research Hypothesis}

There is no significant relationship between Participatory Forest Management and Mau Forest Conservation programme

\subsection{Statement of the Problem}

Kenya has a relatively low forest cover with closed canopy forest covering about 1.24 million hectare while plantations 0.16 million hectare. The total forest area is less than 3 per cent of the total land area of Kenya. A further benefit of the forest is its role in climate regulation as a reservoir and sink of carbon dioxide, the main greenhouse gas (GHG) contributing to global warming and climate change (Hesslerová and Pokorný, 2010).Most of the indigenous forests occur in high potential areas where they are under severe pressure and competition from other forms of land use. The economic importance of the Mau forest is evidenced by the fact that in 2007, the Maasai Mara Reserve and Nakuru Park generated revenue of over USD 10 million from Park entry fees alone (UNEP, 2008).The rivers originating from the Mau produce hydro-electric power with an estimated potential hydropower generation of approx. 535 megawatts, representing $57 \%$ of the total electricity generation capacity in Kenya in 2009 (GOK, 2009. In total, the forest excision and widespread human encroachments led to a total loss of about $25 \%$ of the more than107, 000 ha the Mau between 1989 and 2009 (GOK, 2009).

The Mau Forest Complex (MFC) has undergone significant land use changes due to increased human population demanding land for settlement and subsistence agriculture. The encroachment has led to drastic and considerable land fragmentation, deforestation of the headwater catchments and destruction of wetlands previously existing within the fertile upstream parts. Unfortunately the Forest Act has remained largely unimplemented as the institutional structures for the Kenya Forest Service has not been completed and devolution of forest management powers is not yet to take place (Matiku et al. 2011). The decrease in forest cover is primarily due to encroachment, expansion of human settlements into previously forested areas, illegal logging, forest fires, agriculture and government excisions (NEMA 2009).

\section{Literature Review}

\subsection{Participatory Forest Management and Conservation Programme in Mau Forest}

The participatory approach(PFM) entailed a shift of conservation focus from nature as protected through exclusive state-led, top-down, technocratic control, to nature as managed through inclusive, bottom-up, participatory 
endeavours. This new paradigm is grounded on the argument that "if conservation and development could be simultaneously achieved, then the interests of both could be served". This amalgamation of conservation and development aims has often been termed a "win-win" solution, or "pro-poor" conservation (Adams, 2004).This is done through a process of inclusion, equity, and democratization of governance of the forest resources (Agrawal and Gupta, 2005). Local community participation in utilization and management of forest resources through collective action has become widely accepted as a possible solution to the failure of the centralized, top-down approaches to forest conservation, hence the increased adoption of PFM in most developing countries (Wily, 2001; Agrawal, 2007). There is need to carry out the study to ascertain the influence of PFM on conservation programmes in Mau Forest.

Anders (2000) noted, the foundation of Participatory Forest Management (PFM) is that local community can and will conserve forests if rendered legal right to access and use the resource to generate tangible benefits - a benefit that confers the retaining of the forests rather than removing them. Indeed, PFM is dualistic in purpose - it is about the economic and social benefits of forest dependent community from the forests, as it is about the conservation of the forest resources. In so doing PFM establishes an interface where conservation concerns of the State and the livelihood needs of local communities can be served equitably. PFM is not only about benefit sharing, but also about empowerment and decision making on issues that immediately and vitally concern communities. PFM deals with community participation as they are gaining a new role as forest managers and legal users, and need to be organized, establish appropriate institutions, define their needs, develop plans and implement the plans to achieve a successful forest management and meet their needs.

However, participatory forest planning can be a complicated and delicate task. The complexity springs from the fact that several stakeholders are involved and that these stakeholders very often have conflicting interests; that is, the situation has both a multiple stakeholder and a multiple criteria character. The delicate task is to make the participatory process legitimate and accepted by stakeholders, because the stakeholders may have very different expectations of a participatory process (Kangas, Saarinen, Saarikoski, Leskinen, Hujala, Tikkanen, 2010; Webler and Tuler, 2001).

A simplified version of Arnstein's original ladder of participation, published by the International Association of Public Participation (IAP2, 2007), contains relevant levels that correspond to the use of participation in forest planning situations.

Also, recent thinking has concluded that monitoring is more than a way of generating information; it is a catalyst for learning processes at the core of adaptive forest management. Colfer 2005) discusses how monitoring serves an integral role in the iterative cycle of planning, action, assessment and learning-a cycle that generates systematic progress and adaptation to change (Colfer 2005, Guijt 2007, Fisher et al. 2007). Participatory monitoring, where local community members collect the monitoring data, may be a good alternative. However, for local people and government staff to be successfully involved, the methods must be simple.Akpama (2002) maintained that, people's participation in communal forestry management does not mean just convincing people to carry out the tasks identified for them in the course of management. It means that people either individually or collectively are involved in identifying the problems and their causes and assessing the native scope and magnitude of interventions required to ameliorate crisis.

Evaluation on its part is assessment of ongoing or already completed activities in order to find out how they support decision making and how the objectives are being met. Evaluation can be applied to many initiatives, including projects (UNDP 2009). Evaluation is done in the mid-way or at the end of an initiative, and it is periodical by nature. The evaluation process takes into consideration the wider image and the objectives, which are not as concrete as the outputs, reviewing how successfully the objectives have been achieved.

Hence, in recognition of the role of local forest adjacent communities in reduction of forest destruction and degradation, the Kenyan government introduced the concept of PFM (MENR, 2005, 2016). This was first entrenched by the enactment of the Forest Act (2005) and the subsequent National Forest Act (2016). Under the PFM arrangement in Kenya, the government retains ownership of the forest while forest-adjacent communities, organized in the form of Community Forest Associations (CFAs), obtain user rights. In spite of this, Mau Forest Complex has witnessed a number of positive developments geared towards regeneration. A public-private sector partnership under the auspices of the Save the Mau Trust has stepped up efforts to rehabilitate the degraded portions of the forest. Mbuvi, Maua, Ongugo, Koech, Othim and Musyoki, (2009) states that the emerging PFM is where the state through Kenya Forestry Service (KFS) and communities are both involved in the development of forest management guidelines and agreements.

\subsection{Institutional Framework and Mau Forest Conservation Programme}

The success of PFM projects in some countries like Nepal and India has resulted into sustainable use of forest resources thereby witnessing the contribution of the sector to Millennium Development Goals (Fisher, Prabhu and McDougall, 2007). The initial focus on involving community in government programmes for reforestation and forest protection has also gradually evolved towards more devolution of decision-making power and more active use of forest resource by the local communities.

Governments have a key facilitative role in building technical capacity and empowerment of forest users (Agrawal and Gupta, 2005, Andersson, 2006). Gibson, McKean and Ostrom, (2000) argue that local institutions can help mitigate the some factors responsible for deforestation. These institution include Community Forest User Groups (CFUGs) and Community Forest Association (CFAs). The institutions developed, devise rules and regulations that ensure sustainable livelihoods through access to resources and markets (Ballabh, Balooni and Dave, 2002). However, there have been mixed outcomes on effectiveness of local institutions. For example, in Tanzania, degraded and overused woodlands were regenerated with enforcement of rules, while in Malawi regulation of use and users has been associated with both success and failure (Campbell, Shackleton and Wollenberg, 2003). But, collapse of local institutions has been attributed to lack of 
enabling environment; unsustainable exploitation of the resource; heterogeneity among households; lack of legitimate local institutions and resource characteristics (Campbell et al., 2003). Therefore, the success of participatory forest management (PFM) relies on the collaboration of local people for long-term resource management using local groups as alternative to strict regulation and enclosure (Pretty, 2003). Consequently, creation of formal user groups has been reported to be a key mechanism in enhancing participation of community members in forest management and therefore, generate more functional communities and PFM incentives (Agrawal and Gupta 2005, Zulu, 2012).In Mau Forest for instance, these formal user groups are Community Forest Association (CFA) members who play significant role in implementing afforestation programs.

It is good to note that special services for participatory forestry have been introduced in a growing number of countries (Wily, 2002). Although this is merely identified as a special service, bureau or desk, within the forest department, more and more countries, such as Gambia, Ghana, Guinea Bissau, Kenya, Lesotho, Mali, Morocco, South Africa, Cameroon and Uganda, have units that are explicitly aimed at promoting participatory forestry. Also, the delays in implementation of PFM are caused by inadequate political support, unclear attitudes and commitment among foresters, inadequate empowerment of CFAs, weak local institutions, and failure to devolve accompanying funds and other resources to community institutions.

In order for the local communities to enter into such co-management arrangements, they are legally expected to form and register Community Forest Associations (CFAs) within different forests distributed across the country (MENR, 2007). Lately, the Kenya Forest Service has also been spearheading the formation of CFAs as a step towards meeting the requirements of the Forest Act (2005). These Community based organizations have assumed great importance since the new Forest Act vests management responsibility and benefits with already organized local actors. For example, the government has provided funds to CFAs for a variety of projects such as Plantation Establishment and Livelihood Improvement Schemes. Many CFAs have also benefited from other forest stakeholders such as National Museum of Kenya (NMK), Kenya Wildlife Service (KWS), NGOs and Kenya Forestry Research Institute (KEFRI) that have committed funds for various types of house hold income enhancement schemes.

Mau Forest Complex is the largest closed-canopy montane ecosystem in Eastern Africa. However, in the past three decades or so, the Mau Forest Complex (MFC) has undergone significant land use changes due to increased human population demanding land for settlement and subsistence agriculture. The encroachment has led to drastic and considerable land fragmentation, deforestation of the headwater catchments and destruction of wetlands previously existing within the fertile upstream parts. Today, the effects of the anthropogenic activities are slowly taking toll as is evident from the diminishing river discharges during periods of low flows, and deterioration of river water qualities through pollution from point and non-point sources (Kenya Forests Working Group [KFWG], 2001; Baldyga, Miller, Driesse and Gichaba, 2007).

\subsection{Theoretical Framework}

This research study was guided by Forest Transition theory (Angelsen and Rudel, 2013). Countries go through an initial period of industrialization and economic and population growth, causing increases in deforestation. At a later stage of development, deforestation leads to a perceived decrease in the ability of forests to provide environmental services and goods forcing the government and private sector to provide incentives for policies and activities geared towards tree planting, sustainable forest management, general reforestation and regeneration of forests and conservation of remnant forest areas (Rudel, et al., 2005; Angelsen and Rudel, 2013). This is also the case in Mau Forest as different stakeholders are involved in monitoring forest conservation programs. The conceptual framework which guided the study tried to determine how participatory forest monitoring; independent variable influenced forest conservation program; the dependent variable. This explained how regular planting, thinning and pruning of trees planted, sanctioning of law breakers and even control of cattle grazing within the forest area influence forest conservation.

\section{Research Methodology}

\subsection{Research Paradigm}

The paradigm that guided this study was pragmatism. Concerning mixed methods research as the research approach, Johnson and Anthony (2004) indicate that pragmatism paradigm is the best suited for mixed methods research approach. For this study, both quantitative and qualitative aspects of PFM were investigated which called for the need of pragmatism.

\subsection{Research Design}

Descriptive survey and correlational research designs were used in this study because descriptive and inferential data analysis were required. Both the causal effects of relationships as well as the extent to which the combination of predictor variables influenced the outcome of the dependent variable was desired, which called for descriptive and correlational research design.

\subsection{Target Population}

The study targeted 4100 people comprised of 50 Kenya Forest Service officers (KFS), 100 chairpersons of Community Forest Association (CFAs) committees and 3950 households living adjacent to South West Mau Forest in Bomet County. These households surrounded four administrative units (Kenya Forest Service) departments of Bomet forest stations- Itare, Mara-Mara and Ndoinet (KNBS, 2013). These people were the Community Forest User groups living 
within a distant of one to five Kilometers from the edge of the forest. For every household, one representative who is the household head, alternate head or an adult who had been in the household for a period not less than six months was targeted.

\subsection{Sample Size and Sampling Procedure}

The sample size was determined using Yamane (1967).The formula was used to calculate the sample size (n) given the population size $(\mathrm{N})$ and a margin of error (e). It is a random sampling technique formula to estimate sampling size. The study used a 95\% confidence level, which leads to a significance level of 0.05 .

$n=\frac{N}{1+N E^{2}}$

where:

$\mathrm{n}=$ no. of samples

$\mathrm{N}=$ total population

$\mathrm{e}=$ error margin $/$ margin of error $(0.05)$

$\mathrm{n}=\frac{4100}{1+\left(4100 \times 0.05^{2}\right)}$

$\mathrm{n}=364$

Using this formula, a sample size of 364 respondents were obtained from a target population of 4100 people.

\subsection{Sampling Procedure}

To select the respondents, multi-stage sampling technique was used. This helped the researcher to select respondents through three sampling stages giving respondents more reliable equal chances of being selected starting with selection of sub-locations at the first stage, followed by selection of homesteads at the second stage and finally selection of Households. Oso and Onen (2009) observe that a multi-stage sampling procedure progressively selects smaller areas until the individual members of the sample have been selected through a random procedure. $50 \%$ of the eight sub-locations were arranged alphabetically and every even number was selected. The four selected sub-locations formed the research sub-populations. Then households- research categories were randomly selected the four sub-locations. The households were selected in the field using a systematic random sampling where Kenya Forest Stations were used as the central point. Every 4th homestead to the east and west and 3rd to the north and south was sampled and in each homestead, one household head was randomly selected until 284 households were realized.

Also, Purposive sampling technique was used to select a respondent from every household who was a household head, alternate head or an adult household member who had lived in the household for more than six months (Le, Brick, Diop, and Alemadi, 2013). In addition, purposive sampling technique was also used to select the respondents from Kenya Forest Service officers and Community Forest Association (CFA) executive committees. According to Gay (1981) a correlation research requires thirty (30) cases or more. Therefore, 30 Kenya Forest Service officers were selected and 50 chairpersons of CFA committees.

\subsection{Instruments for Data Collection}

The quantitative data was collected using questionnaires administered to household members (CFUGs) and chairpersons of CFA committees. Also, an interview guide was used to collect the qualitative data administered from KFS officers in Mau forest. The use of an open-interview strategy enables better exposure of the interviewees' personal perspectives, their deeper thoughts, emotions and ambitions (Paton, 1990). Research instruments were pilot tested in Chepalungu Forest in Bomet County. According to Cooper and Schilder (2007), the pilot test should constitute 10\% of the sample, therefore; the pilot test was conducted in line with his recommendation.

Out of the 36 respondents selected, 28 households were selected and 5 Community Forest Association committees responded to the questionnaires. In addition, $3 \mathrm{KFS}$ officers were purposively selected to respond to interview guide.

\subsection{Validity of Research instruments}

There are three types of validity that are of interest to researchers: content related, criterion related and construct validity (Donald and Delno, 2006). Content validity was checked to assess the accuracy with which research instruments captured the variables under investigation through the guidance of research experts from the University of Nairobi, Kenya Forest Service officers and Community Forest Association committees. Construct validity was also ascertained by examining whether a consistent significant proportion of high scores in items investigating independent variables would correlate positively or negatively with scores in items investigating the dependent variable. This was done by comparing several scores from different subjects.

\subsection{Reliability of Research instruments}

The research instruments were tested for reliability using split half technique since it required only one test administration (Allen and Yen, 2002). External reliability was addressed by making the questions straightforward and understandable as possible, and this would decrease misunderstandings and guide direct responses to the questions. To test for internal consistency, Cronbach Alpha coefficient was used. (Cronbach's alpha, 1951). A coefficient of zero implies the tool has no internal consistency while that of one implies complete internal consistency, therefore, this implied that the research instruments were reliable. According to Nunnaly (1978), a score of 0.7 is acceptable reliability coefficient. Hence, 
in the pilot test conducted, the composite Cronbach alpha reliability coefficient for the research instrument was 0.7186 . Then the test instrument used in this study satisfied this criteria and was considered highly reliable and appropriate for data collection.

\subsection{Data Collection Procedures}

Tashakkori and Teddlie, (2010) indicate that the type of data collected is informed by the objectives of the study. The researcher visited the Kenya Forest Service offices in Bomet County, and the local administrative offices for introduction and clearance to undertake research in the region. The researcher recruited research assistants and data quality managers who aided in distributing and collecting questionnaires. The researcher requested the household heads and CFA executive committees to fill the questionnaire as honest as possible and follow up was done to check if the questionnaires were duly filled.

\subsection{Data Analysis Techniques}

Mixed methods data analysis techniques were employed in this study by incorporating both descriptive and inferential data analysis. Quantitative data was coded and entered into Statistical Packages for Social Scientists (SPSS Version 25.0) and analyzed using descriptive and inferential statistics. Qualitative data was analyzed using "discourse analysis and content analysis" while parametric data was analyzed using Pearson's Product Moment Correlation Coefficient (r) and Stepwise Regression (R2) analysis. Also, Hypothesis testing was done using p - value approach.

To test the moderating influence of institutional framework on the relationship between Participatory Forest Management and Mau Forest conservation programme, the following statistical model used for analysis was as follows:

$Y=\beta_{0}+\beta_{1} X_{1}+\beta_{2} X_{2}+\beta_{3} X_{3}+\beta_{4} X_{4}+\beta_{1 Z} X_{1} Z+\beta_{2 Z} X_{2} Z+\beta_{3 Z} X_{3} Z+\beta_{4 Z} X_{4} Z+\varepsilon$

where:

$\mathrm{Y}$ is the dependent variable; Mau Forest conservation programme

$\beta_{0} \beta_{0}=$ constant

$\beta_{\mathrm{i}}$ is the coefficient of $\mathrm{X}_{1} X_{i}$ for $\mathrm{i}=1,2,3,4$

$\mathrm{X}_{1} \quad$ = participatory forest planning

$\mathrm{X}_{2} \quad=$ participatory forest monitoring

$\mathrm{X}_{3} \quad=$ participatory implementation of forest management practices

$\mathrm{X}_{4} \quad=$ participatory evaluation

$\mathrm{Z}$ is the hypothesized moderator (institutional framework)

$\mathrm{B}_{\mathrm{Z}}$ is the coefficient of $\mathrm{X}_{\mathrm{i}}{ }^{*} \mathrm{Z}$ the interaction term between institutional framework and each of the dependent variables for $\mathrm{i}=1,2,3,4$

$\varepsilon$ is the error term.

\section{Discussion of Findings}

\subsection{Influence of Institutional Framework on Mau Forest Conservation Program}

From the findings, $119(40.1 \%)$ of the respondents agreed and 113(38.0\%) strongly agreed with a mean of 3.95 and SD of 1.182 that partnership with external institutions existed for effective conservation of Mau Forest. Stakeholders like James Finlay, Kenya Tea Development Authority and Greenbelt Movement have been facilitating forest conservation activities in Mau Forest. They had offered tree seedlings and also conducted seminars among CFAs members. This was supported by qualitative data obtained from an interview with KFS officer who said that:

"There exists a clear institutional framework aiding Mau Forest conservation programme since there are laws and regulation governing the operations of the CFAs. In addition, technical support is provided by the Kenya Forest Service in conjunction with other partners like KTDA and James Finlay who normally supply CFA members with tree seedlings." KFS officer

The success of participatory forest management (PFM) relies on the collaboration of local people for long-term resource management using local groups as alternative to strict regulation and enclosure (Pretty, 2003).

$113(38.0 \%)$ of the respondents disagreed and $94(31.6 \%)$ strongly disagreed with a mean of 2.27 and SD of 1.237 that there was a good number of trained staff aiding in implementation of forest conservation activities in Mau Forest. Inadequate number of extension officers negatively influenced forest conservation programme as CFA members would not be empowered on best practices for successful implementation of PFM programs. The findings were not in line with those of Faham, Rezvanfar, Shamekhi, (2008) in their study in Iran as they discovered strong positive and significant correlation between extension education course and participation.

Also, 134(45.1\%) of the respondents disagreed and 82(27.6\%) strongly disagreed with a mean of 2.22 and SD of 1.104 that adequate budget and staff were allocated for conservation activities in Mau Forest. Hence, CFA members lack financial resources needed to set up tree nurseries or buy equipment like wheelbarrows needed to run activities successfully. Consequently, 121(40.7\%) of the respondents agreed and 99(33.3\%) strongly agreed with a mean of 3.84 and SD of 1.192 that there was a ready market for forest products obtained from Mau Forest. Availability of markets enabled CFA members to sell None-Timber Forest Products (NTFPs) and obtain funds which is channeled back to conserve the forest. Also, this made them improve their livelihoods and it motivating members to participate further in conservation activities. Despite this, governments have a key facilitative role in building technical capacity and empowerment of forest users (Agrawal and Gupta 2005). 
In addition, $119(40.1 \%)$ of the respondents agreed and 111(37.4\%) strongly agreed with a mean of 3.95 and SD of 1.151 that effective mechanisms were in place for transparent engagement and conflict resolution. Existence of cohesion among CFA members was seen to promote group dynamics which led to a reduction in conflicts thus positively influencing enhancement of PFM practices.

Furthermore, 116(39.1\%) of the respondents agreed and 104(35.0\%) strongly agreed with a mean of 3.82 and SD of 1.252 that there was a well-defined and clear property rights over forest resources to users. Clear property rights was seen to streamline the role of forest users on extraction of forest resources which positively lead to the success of PFM programs. Communities should have powers to access, utilize and benefit from the resource equitably (Cronkleton, Pulhin and Saigal, 2012).

The study sought to establish the correlations between institutional framework and Mau Forest conservation programme and the results are presented on Table 1.

\begin{tabular}{|c|c|c|c|}
\hline \multicolumn{2}{|c|}{ Variables } & $\begin{array}{c}\text { Mau Forest Conservation } \\
\text { Programme }\end{array}$ & $\begin{array}{c}\text { Institutional } \\
\text { Framework }\end{array}$ \\
\hline \multirow{2}{*}{$\begin{array}{c}\text { Mau Forest Conservation } \\
\text { programme }\end{array}$} & Pearson Correlation & 1 & $-.157^{* *}$ \\
\cline { 2 - 4 } & Sig. (2-tailed) & & 0.007 \\
\cline { 2 - 4 } & $\mathrm{n}$ & 297 & 297 \\
\hline \multirow{2}{*}{\begin{tabular}{c} 
Institutional Framework \\
\cline { 2 - 4 }
\end{tabular}} & Pearson Correlation & $-.157^{* *}$ & 1 \\
\cline { 2 - 4 } & Sig. (2-tailed) & 0.007 & 297 \\
\cline { 2 - 4 }
\end{tabular}

Table 1: Correlation Results for Institutional Framework and Mau Forest Conservation Programme **. Correlation Is Significant at the 0.01 Level (2-Tailed)

From the findings, Pearson correlation between institutional framework and Mau Forest conservation programme was $r=-0.1577$. Since $r>0.1$, there was a weak negative correlation between the two variables under investigation. The $p$ value of 0.007 was found to be less than 0.05 level of significance which implies that existence of a good institutional framework guiding forest conservation activities leads to the success of PFM programs. Clear policies and legal framework creates an enabling environment for CFA members to implement forest conservation programs.

$\mathrm{R}$ squared was used to show variation in Mau Forest conservation programme which can be explained by institutional framework. The results are presented on Table 2.

\begin{tabular}{|c|c|c|c|c|}
\hline Model & $\mathbf{R}$ & R Square & $\begin{array}{c}\text { Adjusted R } \\
\text { Square }\end{array}$ & $\begin{array}{c}\text { Std. Error of the } \\
\text { Estimate }\end{array}$ \\
\hline 1 & $.157^{\mathrm{a}}$ & .025 & .021 & 4.45372 \\
\hline
\end{tabular}

Table 2: Model Summary for Institutional Framework and Mau Forest Conservation Programme

a. Predictors: (Constant), Institutional Framework

$\mathrm{R}^{2=} 0.025$ shows how much institutional framework predicts Mau Forest Conservation programme. This implies that $2.5 \%$ of institutional framework brings changes in Forest conservation program which enhances successful implementation of PFM in Mau Forest. But the Standard error is 4.454 which is lower than $5 \%$, therefore, institutionalization of Forest conservation program had a significant positive influence on promoting the aims of PFM projects in Mau Forest.

Moderating influence of Institutional Framework on the Relationship between Participatory Forest Management and Mau Forest Conservation Programme

The study sought to establish the moderating influence of institutional framework on the relationship between Participatory Forest Management and Mau Forest Conservation programme. The variation in the dependent variable that could be explained by the independent variables and moderating variable were presented in two models.

\begin{tabular}{|c|c|c|c|c|c|c|c|c|c|}
\hline \multirow[t]{2}{*}{ Model } & \multirow[t]{2}{*}{$\mathbf{R}$} & \multirow{2}{*}{$\begin{array}{c}\text { R } \\
\text { Square }\end{array}$} & \multirow{2}{*}{$\begin{array}{l}\text { Adjusted } \\
\text { R Square }\end{array}$} & \multirow{2}{*}{$\begin{array}{c}\text { Std. } \\
\text { Error of } \\
\text { the } \\
\text { Estimate }\end{array}$} & \multicolumn{5}{|c|}{ Change Statistics } \\
\hline & & & & & $\begin{array}{c}\text { R Square } \\
\text { Change }\end{array}$ & $\begin{array}{c}\text { F } \\
\text { Change }\end{array}$ & df1 & df2 & $\begin{array}{c}\text { Sig. F } \\
\text { Change }\end{array}$ \\
\hline 1 & $0.109^{a}$ & 0.012 & -.002 & 4.506 & 0.012 & 0.877 & 4 & 292 & 0.478 \\
\hline 2 & $0.195^{b}$ & 0.038 & 0.022 & 4.453 & 0.026 & 7.955 & 1 & 291 & 0.005 \\
\hline
\end{tabular}

Table 3: Model Summary for Moderating Influence of Institutional Framework

From the Table 3, the first model comprised of participatory forest planning, participatory forest monitoring, participatory implementation of forest management practices, participatory evaluation. R square was 0.012 which implied that $1.2 \%$ of Mau Forest conservation programme could be explained by participatory forest planning, participatory forest monitoring, participatory implementation of forest management practices and participatory evaluation. 
The second model constituted participatory forest planning, participatory forest monitoring, participatory implementation of forest management practices, participatory evaluation, institutional framework, participatory forest planning *institutional framework, participatory forest monitoring *institutional framework, participatory implementation of forest management practices *institutional framework, participatory evaluation * institutional framework. R squared was 0.038 which implied that the introduction of institutional framework in the second model led to an increase in r-squared. This showed that institutional framework moderates the relationship between Participatory Forest Management and Mau Forest Conservation programme.

\subsection{Coefficients for Moderating Influence of Institutional Framework}

Table 4, Shows regression coefficients for the moderating influence of institutional framework on Mau Forest conservation programme.

\begin{tabular}{|c|c|c|c|c|c|c|}
\hline \multicolumn{2}{|r|}{ Model } & \multicolumn{2}{|c|}{ Unstandardized Coefficients } & \multirow{2}{*}{$\begin{array}{c}\begin{array}{c}\text { Standardized } \\
\text { Coefficients }\end{array} \\
\text { Beta } \\
\end{array}$} & \multirow[t]{2}{*}{$\mathbf{t}$} & \multirow[t]{2}{*}{ Sig. } \\
\hline & & B & Std. Error & & & \\
\hline \multirow[t]{5}{*}{1} & (Constant) & 32.794 & 3.398 & & 9.650 & .000 \\
\hline & $\begin{array}{l}\text { Participatory Forest } \\
\text { Planning }\end{array}$ & .090 & .055 & .098 & 1.651 & .100 \\
\hline & $\begin{array}{c}\text { Participatory Forest } \\
\text { Monitoring }\end{array}$ & -.023 & .063 & -.022 & -.374 & .708 \\
\hline & $\begin{array}{c}\text { Participatory } \\
\text { implementation of } \\
\text { forest management } \\
\text { practices }\end{array}$ & -.002 & .059 & -.002 & -.039 & .969 \\
\hline & $\begin{array}{c}\text { Participatory } \\
\text { evaluation }\end{array}$ & -.053 & .052 & -.060 & -1.018 & .309 \\
\hline \multirow[t]{6}{*}{2} & (Constant) & 38.506 & 3.922 & & 9.818 & .000 \\
\hline & $\begin{array}{l}\text { Participatory forest } \\
\text { planning }\end{array}$ & .100 & .054 & .109 & 1.860 & .064 \\
\hline & $\begin{array}{c}\text { Participatory Forest } \\
\text { Monitoring }\end{array}$ & -.019 & .062 & -.018 & -.313 & .755 \\
\hline & $\begin{array}{c}\text { Participatory } \\
\text { implementation of } \\
\text { forest management } \\
\text { practices }\end{array}$ & -.012 & .058 & -.012 & -.203 & .839 \\
\hline & $\begin{array}{c}\text { Participatory } \\
\text { evaluation }\end{array}$ & -.050 & .051 & -.057 & -.984 & .326 \\
\hline & $\begin{array}{l}\text { Institutional } \\
\text { framework }\end{array}$ & -.189 & .067 & -.163 & -2.820 & .005 \\
\hline
\end{tabular}

Table 4: Coefficients for Moderating Influence of Institutional Framework

In the first model, by substituting the beta values and constant term, model 1 formed form the first step in regression modeling was as follows:

$\mathrm{Y}=32.794+.090 \mathrm{X}_{1}+-.023 \mathrm{X}_{2}+-.002 \mathrm{X}_{3}+-.053 \mathrm{X}_{4}$

The findings show that participatory forest planning has a significant positive influence on Mau Forest conservation program as shown by a regression coefficient of $0.090(p$-value $=0.100)$. This is supported by other scholars who said that Participatory forest planning can be a complicated and delicate task. The delicate task is to make the participatory process legitimate and accepted by stakeholders, because the stakeholders may have very different expectations of a participatory process (Kangas et al., 2010; Webler and Tuler, 2001).

In addition, participatory forest monitoring has a significant negative influence on Mau Forest conservation programme as shown by a regression coefficient of -.023 (p-value=0.708). This validates the findings of other scholars that where resource users regularly monitor and sanction resource use, the condition of forest resources will likely be better than where rules are not enforced (Gibson, Andersson, Ostrom and Shivakumar, 2005).

Moreover, participatory implementation of forest management practices has a significant negative influence on Mau Forest conservation programme as shown by regression coefficient of -.002 ( $p$-value=0.969). Participatory evaluation has a significant negative influence on Mau Forest conservation programme as shown by regression coefficient of -.053 (p-value $=0.309$ ).

In the second regression model, by substituting beta values and the constant term, model 2 emanating from the second step in regression modeling was as follows:

$\mathrm{Y}=32.794+0.90 \mathrm{X}_{1}+-0.023 \mathrm{X}_{2}+-0.002 \mathrm{X}_{3}+-0.053 \mathrm{X}_{4}+.100 \mathrm{X}_{1} * \mathrm{Z}+-.019 \mathrm{X}_{2} * \mathrm{Z}+-.012 \mathrm{X}_{3} * \mathrm{Z}+-.050 \mathrm{X}_{4} * \mathrm{Z}$

The findings show that by introducing the moderator, institutional framework to the model, participatory forest planning has a significant positive influence on Mau Forest conservation program as shown by a regression coefficient of $0.100(p$-value $=0.064)$. Also, participatory forest monitoring has a significant negative influence on Mau Forest 
conservation programme as shown by a regression coefficient of -.019 (p-value=0.755). Moreover, participatory implementation of forest management practices has a significant negative influence on Mau Forest conservation programme as shown by regression coefficient of -.012 (p-value=0.839). Participatory evaluation has a significant negative influence on Mau Forest conservation programme as shown by regression coefficient of -.050(pvalue=0.3326). Consequently, institutional framework has significant negative influence on Mau Forest conservation programme as shown by regression coefficient of -.189 (p-value $=0.005)$. Creation of formal user groups has been reported to be a key mechanism in enhancing participation of community members in forest management and therefore, generate more functional communities and PFM incentives (Agrawal and Gupta 2005, Zulu, 2012). Community participation is achieved primarily through CFAs, and integrated management of forests is the central principle motivating the new policy (Ongugo, et al., 2007). On the other hand, Kayambazinthu et al. (2003) indicated that institutions that are based on tradition and culture are given legitimacy at local level and are more stable and lasting.

\subsection{Testing of Hypothesis 7}

The null hypothesis was that: The relationship between Participatory Forest Management and Mau Forest conservation programme does not depend on institutional framework. The p-value was found to be 0.005 which is less than 0.05, therefore, null hypothesis was rejected and concluded that the relationship between Participatory Forest Management and Mau Forest conservation programme depends on institutional framework.

\section{Conclusion}

The study concludes that a clear institutional framework significantly influence effective conservation of Forestsbecause it empower forest institutions such as Community Forest associations to engage in participatory processes meant for promotion of Participatory Forrest Management programmes for sustainability of forests.

\section{Recommendation}

The recommendation made is that local institutions such as Community Forest associations (CFAs)need to be built by be equipping them with resources, training and property rights so as to make them downwardly accountable. Additionally, effective leadership needs to be provided where it is missing or strengthened where it is present. The government, Non-governmental Organizations (NGOs) and donor support should continue to provide the required technical and monetary support to CFAs for effective implementation of Participatory Forest Management programmes.

\section{References}

i. Abbas, D. (2007). Harvesting forest biomass for energy in Minnesota: An assessment of guidelines, costs and logistics.Ph.D. Dissertation, University of Minnesota, Minnesota, U.S.A.

ii. Adams, W. M. "Biodiversity Conservation and the Eradication of Poverty. "Science306 (2004).

iii. Agarwal A, and Gupta K. (2005). Decentralization and participation: The governance of common pool resources in Nepal's Terai. World Dev., 33: 1101-1114.

iv. Agarwal, B. (2007). Gender inequality, cooperation and environmental sustainability. Pages 274-313

v. Allen, M.J. \&Yen, M.W. (2002). Introduction to measurement theory. Long Grove, IL: Waveland press.

vi. Akpama, S.I (2002). "Effective Communication as Potent Instrument for Promoting Sustainable

vii. Management of Environmental Resources”. In Umoren G. Ntia, N.U. \& Biao, I. (eds)

viii. Reading in Adult Education. Calabar: Glad Tiding Press Ltd.

ix. Anders S. (2000) Guidelines for participatory forest management planning. FARMAfrica, Addis Ababa

x. Andersson, K. (2006). Understanding decentralized forest governance: an application of the institutional analysis and development framework. Sustainability: Science, Practice and Policy 2(1): 25-35.

xi. Angelsen, A., and Rudel T.K. (2013). Designing and implementing effective REDD+ policies: a forest transition approach Rev. Environ.Econ. Policy 7,91-113

xii. Baldyga, T. J., Miller, N. S., Driesse, L. K., \& Gichaba, N. C. (2007). Assessing land cover change in Kenya's Mau Forest region using remotely sensed data. African Journal of

xiii. Ecology, 46, 46-54, doi:10.1111/j.1365-2028.2007.00806.x

xiv. Ballabh, v., Balooni, K and Dave ,S.(2002) Why local resources management institution declare- A comparative analysis of van (forest) panchayats and forest protection communities in India world development 30:21532167.

xv. Campbell, B.M., Shackleton, S. and Wollenberg, E. (2003). Overview: Institutional arrangements for managing miombo. In: Kowero G., Campbell B.M. And Sumaila U.R. (ed.) Policies and Governance Structures in Woodlands of Southern Africa. Centre for International Forestry Research, Indonesia. 438pp.

xvi. CBD (2009).A Good Practice Guide for Sustainable Forest Management, Biodiversity and Livelihoods.

xvii. Colfer, C. J. P. (2005). The complex forest: Communities, uncertainty, and adaptive

xviii. collaborativemanagement. Washington DC, USA: RFF/CIFOR.

xix. Cooper, D., \&Schindler, P. (2007). Business Research Methods.NewYork, McGraw-Hill Higher Education

xx. Cronbach, L. J. (1951). Coefficient alpha and the internal structure of tests.psychometrika, 16(3), $297-334$.

xxi. Cronkleton, P., Pulhin, J.M., Saigal, S. (2012). Co-management in community forestry: How the partial devolution of management rights creates challenges for forest communities. Conservation and Society, 10(2):91-102

xxii. $\quad$ Donald K.K \& Delno, L.A. (2006). Proposal and Thesis writing. Paulines Publications. Africa. ISBN 9966 -08 $133 \mathrm{X}$ 
xxiii. FAO (2010). Global forest resources assessment 2010 Nepal. Country report, Food and Agriculture Organization, Rome.

xxiv. Faham, E., Rezvanfar, A., \&Shamekhi, T. (2008). Analysis of Socio-Economic Factors Influencing Forest Dwellers' Participation in Reforestation and Development of Forest Areas: The case Study of West Mazandaran, Iran. American Journal of Agricultural and Biological Sciences 3(1):438-443,2208

xxv. Fisher, R., Prabhu, R., \& McDougall, C. (2007). Introduction: People, forests and the need for adaptation. Adaptive collaborative management of community forests in Asia: Experiences from Nepal, Indonesia and the Philippines. Bogor, Indonesia: Center for International

xxvi. Forestry Research (CIFOR).

xxvii. Forest Act (2005) - Government of Kenya. (2005). Forests Act 2005. Nairobi, Kenya: The Government Printer

xxviii. Gay, L. R. (1981).Education Research: competencies for Analysis and application (Charles E. Mairill Publishing Company, Bell, A. and Howell Company. Columbus, Toronto and London,

xxix. Gibson, C., M.A. McKean, and E. Ostrom (eds). (2000). People and Forests: Communities, Institutions, and Governance. Cambridge: MIT Press.

xxx. Gibson, C. G., J. T. Williams, and E. Ostrom. 2005. Local enforcementand better forests. World

xxxi. Development 33:273-284.

xxxii. GOK (2009). Rehabilitation of the Mau Forest Ecosystem. A Project Concept prepared by the Interim Coordinating Secretariat, Office of the Prime Minister, on behalf of the Government of Kenya Government of Kenya (2014). Ministry of Environment, Water and Natural Resources; Draft National Forest Policy.

xxxiii. Guijt, I. (ed.).(2007). Negotiated learning: collaborative monitoring in forest resources management. Resources for the Future, Washington, D.C., USA.

xxxiv. Hesslerová, P. and Pokorný, J. (2010) Effect of Mau Forest Clear Cut on Temperature

xxxv. Distribution and Hydrology of Catchment of Lakes Nakuru and Naivasha: Preliminary Study.

xxxvi. In: Water and Nutrient Management in Natural and Constructed Wetlands, Springer,

xxxvii. $\quad$ Netherlands, 263-273. http://dx.doi.org/10.1007/978-90-481-9585-5_19

xxxviii. IAP2. (2007). IAP2 Spectrum of Public Participation.

http://www.iap2.org/associations/4748/files/IAP2\%20Spectrum_vertical.pdf. Accessed 4 January, 2010.

xxxix. Johnson, R. B., \& Onwuegbuzie, A. J. (2004). Mixed methods research: A research paradigm whose time has come. Educational Researcher, 33(7), 14-26.

xl. Kaimowitz, D. (2003). Not by Bread Alone...Forests and Rural Livelihoods in Sub-Saharan Africa. In Forests in Poverty Reduction Strategies: Capturing the Potential, EFI Proceedings No. 47, ed. T. Oskanen, B. Pajari, and T. Tuomasjukka. Joensuu, Finland: European Institute.

xli. Kangas, A., Saarinen, N., Saarikoski, H., Leskinen, L.A., Hujala, T., Tikkanen, J., (2010). Stakeholder perspectives about proper participation for Regional Forest Programmes in Finland. For. Policy Econ. 12, 213-222.

xlii. Kayambazinthu, D., Matose, F., Kajembe, G. and Nemarundwe, N. (2003). Institutional arrangements governing natural resource management of the miombo woodland. In: KOWERO G., CAMPBELL B.M. and SUMAILA U.R. (ed.) Policies and Governance Structures in Woodlands of Southern Africa. Centre for International Forestry Research, Indonesia.

xliii. Kenya National Bureau of Statistics., (2013). Kenya Facts and Figures 2013. http://www.knbs.or.ke/index/kenyafacts2013.pdf. 20/5/2014.

xliv. KFWG. (2001). Kenya Forests Working Group. Excision and settlement in the Mau Forest. Report of Kenya Forest Working Group, Nairobi, Kenya, pp.15.

xlv. Lee D.K. and Park Y.K. (2001). Degradation Issues in Southeast and Northeast Asia.

xlvi. Proceedings of 10th International workshop of BIO-REFOR [M]. The University of

xlvii. Tokyo, Tokyo, 2001: 3-24

xlviii. Le, K. T., Brick, J. M., Diop, A., and Alemadi, D. (2013). "Within-household Sampling Conditioning on Household Size." International Journal of Public Opinion Research, 25, 108-118.

xlix. Matiku P, Ogol C, Mireri C. (2011). The impact of participatory forest management (PFM) on forest integrity and biodiversity in Arabuko-Sokoke forest, Kenya. Afr. J. Ecol., Doi: 10.1111/j.1365-2028.2011.01311.x

1. Mbuvi, M.T.E., Maua, J.O., Ongugo, P.O., Koech, C.K. Othim, R.A. and Musyoki, J.K. (2009).

li. Status of the Participatory Forest Management impacts on Poverty for Buyangu non-PFM area adjacent community: Kakamega Forest; Kakamega District. Kenya Forestry Research

lii. Institute (KEFRI).

liii. MENR (2016). The kenya forest act, 2016. Ministry of Environment and Natural Resources.

liv. MENR (2005). The kenya forests act, Ministry of Environment and Natural Resources.

lv. Ministry of Environment and Natural Resources (MENR). (2007).Participation in Sustainable Forest Management.2007 Draft Rules and Guidelines.

lvi. Mustalahti I. (2006). How to handle the stick: Positive processes and crucial barriers of Participatory Forest Management. Forests, Trees and Livelihoods, 16 (2), 151-165.

lvii. NEMA, (2009). Fourth National Report to the Conference of Parties to the Convention on

lviii. Biodiversity

lix. Neumann, R.P. (2005). Making political ecology. London: Hodder Arnold.

lx. Nunnaly, J. (1978). Psychometric theory. New York: McGraw-Hill. 
lxi. Ongugo, P.O., Mbuvi, M.T.E., Maua, J.O., Koech, C.K. \&Othim, R.A. (2007). Emerging Community Institutions for PFM Process Implementation in Kenya. A paper presented to the $3^{\text {rd }}$ International PFM Conference. Addis Ababa. Ethiopia.

lxii. $\quad$ Oso \& Onen (2009) A general guide to writing research proposal and report.Options press \& Publishers

lxiii. Phiri, M., Chirwa, P. W., Watt, S. \& Syampungani, S. (2012). Local community perception of joint forest management and its implications for forest condition: the case of Dambwa Forest Reserve in southern Zambia. Southern Forests, 74, 52-59.

lxiv. Porharel, R. K. (2008) Nepal's community forest funds: Do they benefit the poor? SANDEE working paper No.3108. Kathmadn: SANDEE.

lxv. Pretty, J. (2003). Social Capital and the Collective Management of Resources. Science 302 (5652):1912-1914.

lxvi. $\quad$ Rudel, T. K., Coomes, O. T., Moran, E., Achard, F., Angelsen, A., Xu, J. and Lambin, E.,

lxvii. (2005). Forest transitions: toward a global understanding of land-use change. Global

lxviii. Environ. Change, 2005,15,23-31.

lxix. Tashakkori, A., and Teddlie, C. (2010). Handbook of Mixed Methods in Social and Behavioral Research. Thousand Oaks, CA: Sage.

lxx. URT (2003) Participatory Forest Management: A Report on Lessons Learnt. In Ministry of Natural Resources and Tourism, Forestry and Beekeeping Division, National Forest Programme (Ed). Dar es Salaam, Forestry and Beekeeping Division.

lxxi. $\quad$ UNEP. (2002). Global Environmental Outlook 3: Past, Present and Future Perspective. (London: Sterling V.A. Earth Scan Publication Ltd, 2002).

lxxii. Webler, T., Tuler, S., Krueger, R.O.B.(2001). What is a good public participation process? Five perspectives from the public. Environ. Manag. 27, 435-450.

Ixxiii. Wily, L. A. (2001). Forest management and democracy in East and Southern Africa: lessons from Tanzania. International Institute for Environment and Development.

lxxiv. Wily, L.A. (2002). Participatory Forestry in Africa: An Overview of Progress and Issues. In Second International Workshop on Participatory Forestry in Africa: Defining the Way Forward: Sustainable Livelihoods and Sustainable Forest Management Through Participatory Forestry. Proceedings of the Second International Workshop on Participatory Forestry in Africa.

lxxv. World Bank (2006). Agricultural Investment Sourcebook. Module 12 "Scaling Up Agricultural Investments in the Bank's Changing Internal Environment." Washington, D.C.

lxxvi. Yamane, Taro. (1967). Statistics: An Introductory Analysis, 2nd Ed. New York: Harper and Row.

lxxvii. Zulu, L.C. (2012). Neoliberalization, decentralization and community-based natural resources management in Malawi: The first sixteen years and looking ahead. Progress in Development Studies, 12(2/3): 193 -212. DOI: $10.1177 / 146499341101200307$ 